UDC 338.242

DOI: https://doi.org/10.32782/2413-9971/2020-34-9

\author{
Danylenko-Kulchytska Viktoriya \\ PhD in Economics, \\ Associate Professor, \\ Senior Lecturer at the Department of \\ International Tourism and Hotel Business \\ West Ukrainian National University
}

Даниленко-Кульчицька В. А. кандидат економічних наук, доцент, доиент кафедри міжнародного туризму і готельного бізнесу Західноукраӥнського національного університету

\title{
WAYS TO REDUCE THE NEGATIVE IMPACT OF THE COVID-19 PANDEMIC ON THE DEVELOPMENT OF TOURISM IN THE WORLD AND IN UKRAINE
}

Summary. The article considers the impact of the COVID-19 pandemic on the tourist market of the world and Ukraine. It is noted that any crisis leads to new opportunities. The main trends of the pandemic's impact on various aspects of the hospitality sector are analyzed, which show that the crisis has hit international tourism the hardest, and domestic travel the least. Possible directions for the tourist sphere to develop in the future are considered. Those are, namely, increasing requirements for travel safety, individualization of tourism, extensive use of the latest information technologies in tourism, the use of ideas of the economy of impressions, expanding the geography of tourist routes. Ways to mitigate the negative impact of this crisis on domestic tourism enterprises based on the use of foreign experience are proposed. Ukrainian tourism companies are encouraged to focus primarily on the resumption of domestic tourism, tourism companies with the assistance of the government can prepare several long recreational tourist routes (from west to east, from north to south), placing along them shopping malls, accommodation, outdoor entertainment, discount restaurants, etc.

Key words: tourism, tourist market, the COVID-19 pandemic, crisis, domestic tourism, prospects for recovery, ways to overcome the crisis, innovations in tourism.

Introduction and formulation of the problem. Tourism is an important part of the economy of many countries. In 2020, the global tourism industry experienced a serious crisis associated with the rapid spread of a new species of coronavirus (COVID-2019) around the world. The World Travel and Tourism Council (WTTC) estimates that more than 197 million hospitality jobs could be lost as a result of COVID-19, with an estimated 3.4 trillion USD in financial losses to the sector by the end of 2020 [5]. Long-term travel restrictions will also reduce the industry's contribution to world GDP by 4.7 trillion USD, or 53\%, compared to 2019 , the organization notes [3]. All this means that the hospitality market can expect inevitable changes and how quickly both the global tourism market and the tourism markets of individual countries will be able to adapt to new realities will have a direct impact on the state and existence of these markets in general.

Analysis of recent research and publications. Many scientists and researchers deal with the impact of various economic crises on the tourism industry. Today, leading economists together with representatives of the tourism 
industry are trying to find ways out of the crisis, consider new opportunities in the tourism market, trying in one way or another to reorient themselves according to new world requirements. In particular, Oliver Wyman studies the future of travel and tourism using a mathematical approach, Paul Griffiths focuses on the impact of the pandemic on global aviation, President of the American Travel Association and tourism researcher Roger Dow studies the impact of the crisis on the US tourism industry. However, among these studies there is no analysis of the impact of the pandemic on the domestic tourism market. That is why finding out the peculiarities of the impact of the COVID-19 pandemic on the development of the tourism industry of Ukraine is an urgent scientific problem.

The aim of the article is to analyze the impact of the COVID-19 pandemic on the state of the global tourism industry and to suggest ways to reduce its negative effects.

Research results. Today, tourism is rightly considered a phenomenon of the 21 st century, because more than 150 of the 195 countries are involved in tourism. In recent decades, world tourism has shown steady growth. The World Tourism Organization (UNWTO) estimates that the number of tourist arrivals worldwide in 2030 will be 1.36 billion. In other words, every fifth inhabitant of the planet will make tourist trips. Globally, tourism accounts for about $10 \%$ of GDP and more than $6 \%$ of world exports [1].

However, everything changed in early 2020, when all countries of the world were affected by a pandemic of a new type of virus - COVID-19. The virus, the first outbreak of which was recorded in the Chinese city of Wuhan in December 2019, has gradually spread to all countries and continents. As of November 1, 2020, more than 46.5 million cases of infections were detected worldwide, more than 1.2 million people died.

The fundamental difference between the current pandemic and those that humanity has encountered before (plague pandemic, the Spanish flu, etc.) is the simultaneous emergence of the so-called "pandemic of fear", associated with the rapid development of information technology and the rapid spread of information in the modern world. After all, the borders of most countries were rapidly closed, transport connections were practically stopped, and a regime of restrictions on movement was introduced in many countries.

The pandemic came to Ukraine in early March. On March 12 , the national government announced a general "lockdown". Many spheres of life have been practically paused including tourism industry. According to a poll conducted by the sociological group "Rating", conducted on August 5, 2020, $66 \%$ of Ukrainians have not been on vacation and do not plan it for this year. Among those who have already been on vacation or plan to do so, $43 \%$ will spend it in their locality, about the same number - in another region of Ukraine. Only $9 \%$ of respondents have been on vacation abroad or are planning such a trip. Those who plan a vacation are more among younger and more affluent people [2].

All this could not but have a significant impact on all areas of the world economy, including tourism. Almost all experts are unanimous in concluding that such a crisis in tourism has not been observed since World War II. However, as we know, any crisis is, at the same time, new horizons and opportunities. Those tourism companies that will be able to quickly adapt to the new conditions will receive significant benefits.

The World Tourism Organization has developed its own recommendations for mitigating the socio-economic impact of the pandemic on tourism in different countries. The World Health Organization (WHO), the International Civil Aviation Organization (ICAO), the Airport Council International (ACI), the Cruise Lines International Association (CLIA), the
International Air Transport Association (IATA), and the World Travel and Tourism Council (WTTC) and many more have also taken part in their development. These recommendations can be divided into three separate blocks:

1. Crisis management and mitigation: job retention; liquidity support of companies; revision of the amount of taxes and fees related to the tourism industry; consumer protection; improving the digital skills of employees in the tourism industry; inclusion of tourism in the general strategies of rescue of economy of various regions and the states, creation of mechanisms of anti-crisis management;

2. Stimulating the accelerated recovery of tourism: stimulating investment in tourism; ensuring the preparation of tourists for travel, creating new jobs; market understanding and prompt response to events in the market of tourist services; increasing the role of marketing; creation of a special governing body that regulates the resumption of tourism);

3. Preparation for the future: diversification of markets, products and services, investment in market research systems and digital transformation; improving the efficiency of tourism management at all levels; ensuring preparedness for crisis situations; investment in human capital; transition to a waste-free economy [6].

It is important to note that the recovery of the tourism sector will not be possible without comprehensive state support. Governments in many countries have realized this and have begun to implement various measures to support the tourism business. For example, Japan will spend 3.6 billion JPY to improve information for travelers and promote tourism, Norway has reduced the VAT rate for travelers from $12 \%$ to $8 \%$, Malaysia is deferring tax payments for six months for the tourism sector, as opposed to three months for other sectors, Germany offers interestfree loans to the tourism business, Hong Kong has allocated an additional 90.2 million EUR to its Tourism Council, the UK has set up a 25,000 GBP grant scheme for hospitality businesses. Italy, Egypt, the Kingdom of Saudi Arabia, and Dubai have also launched new tourism promotion campaigns.

Unfortunately, the tourism sector in Ukraine is not stimulated in any way and there is no state support in this area, which is undoubtedly due to the general weakness of the domestic economy.

Scientists predict that the recovery of the tourism sector will begin with the resumption of domestic tourism and this is a global trend. Thus, almost $77 \%$ of Chinese travelers preferred domestic travel after quarantine; according to the survey, $71 \%$ of Americans want to make domestic tourist trips (last year there were only $58 \%$ ). Approximately the same percentage is typical for other countries. This is primarily due to the aforementioned "epidemic of fear", the fear of getting infected or quarantined away from home. It is also worth noting that domestic tourism has suffered somewhat less than the international one since the crisis, as in most parts of the world, domestic travel has either resumed or not stopped at all. As for Ukraine, at the beginning of the quarantine (spring) tourists preferred individual trips by their own transport over short distances (usually $20-30 \mathrm{~km}$ from home). Fashion at the location was formed through social networks. That is, travelers decided where to go after seeing an attractive photo of the tourist location on Instagram or Facebook. While mass long-distance tourism has stopped almost completely. With the onset of summer and a certain easing of quarantine restrictions, Ukrainians began to travel to inland seas and mountains. In the summer the most popular was a beach holiday in the areas of Koblevo, Zatoka, Odesa, Berdiansk, KarolinoBuhaz. The greatest dynamics is shown by the seaside resorts and settlements of the Sea of Azov in the Zaporizhzhia and Donetsk regions - Berdiansk and Kyrylivka. The demand for holidays in the Carpathians was also high. According to the analysis of the 
Internet traffic and the number of $4 \mathrm{G}$ users conducted by Vodafone Ukraine, in 2020, domestic tourism in the seaside resorts of Odesa, Mykolaiv and Kherson regions grew by $30 \%$ compared to the same period in 2019. Among the new destinations, Vodafone Ukraine singles out the coastal settlements of the Donetsk region: Bilosaray Spit $(+177 \%)$, Yalta $(+124 \%)$, Urzuf $(+101 \%)$. They showed the highest increase in traffic [4].

Another change that awaits the tourist market will be the rejection of the masses. Increasingly, people are abandoning group tours in favor of individual travel. Due to COVID-19, many travelers are rethinking the requirements for tourist destinations and choose green or rural tourism, extreme tours and trips to remote regions instead of all-inclusive beach holidays.

Some domestic travel companies were able to catch this trend and reorient in time. In particular, the tour operator "Join UP" noted that in 2020 the flow of tourists within the country increased significantly in the more expensive segment - the so-called "VIP vacation". This is due to the closure of borders and forced rest in Ukraine for those who have always vacationed abroad. The average check for such a holiday is 2 thousand UAH per night and above for a double room; in 2019 there were popular hotels with an average check of 900 UAH per day [2]. By increasing the demand for such comfort-class objects, the tour operator decided to sell them on the market at a higher price, so it was able to mitigate the negative effects of the crisis on the tourism market. Therefore, travel companies in the world and in Ukraine should monitor changes in demand for travel services carefully and try to meet them as quickly and fully as possible, which will allow them to reduce the negative impact on the sector.

Another requirement for a potential tourist during a pandemic and uncertainty is booking flexibility. Studies in the United States have shown that nearly $70 \%$ of tourists are reluctant to change the date without penalty to persuade them to book a vacation during the COVID-19 outbreak - more than any other factor, including security measures [5].

That is why the accommodation should abandon the desire to protect themselves from the arrival of the client by setting a penalty for cancellation of the reservation, and vice versa to resort to a more loyal to the client booking system. This will increase the number of bookings and, consequently, the number of arrivals.

The crisis has also hit the cultural tourism sector hard, as virtually all museums, theme parks and other cultural sites are closed or restricted. Some enterprises of cultural and cognitive tourism try to arrange virtual tours, but this is not enough to stay in the market. Such companies can be recommended to apply a flexible pricing policy. Theme parks, museums and other attractions can use dynamic prices as a way to manage demand, when prices increase with the number of tickets sold on a given date, and, conversely, decrease if tickets are sold few. Such advanced booking will also make it easier to comply with security requirements for physical distance and limit the number of visitors.

Unfortunately, forecasts show that due to the pandemic, the business tourism market is experiencing a deep and irreversible decline. After all, humanity has learned to successfully use such platforms for business negotiations as Zoom, Google Meet and more. And in the future they will replace the lion's share of business trips. Therefore, those domestic and foreign tourism enterprises, which are mainly engaged in the organization of business tourism should be reoriented to other areas immediately.

As mentioned above, any crisis inevitably leads to new opportunities. Thus, COVID-19 became a catalyst for tourism in terms of innovation and integration of new technologies.
Scientists predict the following areas of technological innovation in tourism:

- wide use of devices that allow to reduce the physical contact of the client during the trip (viewing the menu on their own devices, access to the functions of hotel rooms through their phones, etc.);

- integrated digital solutions that provide unobstructed travel through biometric verifications and electronic gates at airports;

- contactless payments to facilitate the traveler's journey;

- non-contact options for face confirmation (using noncontact fingerprints, iris of the eye);

- Virtual medical examinations at airport

- use of disinfecting robots with ultraviolet radiation, which are already used in hospitals;

- use of concierge services sold through the application;

- use of receptionist robots, etc.

It is worth noting that most of these technologies of the future domestic tourism enterprises are still unable to provide. However, the situation is changing and if, for example, an electronic menu (using a QR code) or the possibility of cashless payment is now available in most Ukrainian restaurants and accommodation, it is hoped that other innovations will soon take place in domestic tourism.

Also, domestic travel companies can implement such a type of tourism in a pandemic as the creation of virtual tours. After all, today more than 2,000 world museums and archives from around the world in cooperation with the Google Cultural Institute have already moved to the Internet through virtual reality.

For hotels that, like the rest of the hospitality industry, are in deep crisis, the solution may be to refocus on providing temporary accommodation to people who are in isolation or rent a room to work remotely without having the opportunity at home. Hotels can also sell vouchers for future accommodation at a reduced price today, but with the prospect of rising prices in the future.

In general, domestic tourism is projected to be the first segment to recover, followed by regional short-haul transport, then medium-distance transport between regions and, finally, international travel. To benefit from the initial recovery, governments, tourism councils, and tourism organizations should focus marketing and promotional efforts on stimulating domestic and regional travel to build tourists' desire to visit nearby routes and attractions.

Ukraine can also use this approach effectively. For example, with the assistance of the government, travel companies can prepare several long recreational tourist routes (from west to east, from north to south), placing outlets along them, accommodation events, organizing outdoor entertainment, discount restaurants and more.

Conclusions. Thus, although the COVID-19 pandemic in early 2020 has had a major impact on the state and further development of the tourism industry, any crisis leads to negative consequences, and also to the emergence of new opportunities and prospects for the tourism market. Among these opportunities there are the acceleration of the processes of digitalization of tourist services, more active introduction of modern technologies, the use of ideas of the economy of impressions, the actualization of an individual approach to the client, the expansion of the geography of tourist routes and others. In addition, the importance of such factors as travel safety (including the sanitary and epidemiological situation of the place of residence) is expected to increase. Tourists will prefer individual tours or tours in small groups at inland resorts. After the pandemic, a new stage of competition in tourism will begin, which will lead to a completely new distribution of resources in this market. 


\section{Список використаних джерел:}

1. Логунцова И.В. Индустрия туризма в условиях пандемии коронавируса: вызовы и перспективы. Государственное управление. Электронный вестник. 2020. № 80. URL: http://e-journal.spa.msu.ru/uploads/vestnik/2020/vipusk_80._ijun_2020_g./ problemi_upravlenija_teorija_i_praktika/loguntsova.pdf (дата звернення: 01.11.2020).

2. Рихліцький В. Внутрішній туризм в Україні мав би рости: як змінилась галузь і куди зник “бюджетний” мандрівник. Eкономічна правда : веб-сайт. URL: https://www.epravda.com.ua/publications/2020/09/23/665405/ (дата звернення: 25.10.2020).

3. У сфері туризму більше половини робочих місць можуть зникнути. Економічна правда : веб-сайт. URL: https:/www.epravda.com.ua/news/2020/10/31/666801 (дата звернення: 01.11.2020).

4. Число туристів на курортах Одеської, Миколаївської та Херсонської областей зросло на 30\% - “Vodafone Україна”. Iнтерфакс Україна : веб-сайт. URL: https://interfax.com.ua/news/telecom/673327.html (дата звернення: 26.10. 2020).

5. To Recovery \& Beyond: The Future of Travel \& Tourism in the Wake of COVID-19. Analysys. World Travel \& Tourism Council (WTTC) : веб-сайт. URL: https://wttc.org/Research/To-Recovery-Beyond (дата звернення 01.11.2020)

6. UNWTO призывает к поддержке экономики через сектор путешествий и туризма. Ежедневная электронная газета Российского союза туриндустрии : веб-сайт. URL: https://ratanews.ru/news/news_6042020_6.stm (дата звернення: 21.04.2020).

\section{References:}

1. Loguntcova I.V. (2020) Industriia turizma v usloviiakh pandemii koronavirusa: vyzovy i perspektivy [The tourism industry in the context of the coronavirus pandemic: challenges and prospects]. Gosudarstvennoe upravleniye [Public administration] (electronic journal), no. 80. Available at: http://e-journal.spa.msu.ru/uploads/vestnik/2020/vipusk_80._ijun_2020_g./problemi_ upravlenija_teorija_i_praktika/loguntsova.pdf (accessed 01 November 2020).

2. Rykhlitskyi V. (2020) Vnutrishnii turyzm v Ukraini mav by rosty: yak zminylas haluz ti kudy znyk "biudzhetnyi" mandrivnyk [Domestic tourism in Ukraine should grow: how the industry has changed and where the "budget" traveler has disappeared]. Ekonomichna pravda [Economic truth] (electronic journal). Available at: https://www.epravda.com.ua/publications/2020/09/23/665405/ (accessed 25 October 2020).

3. Economic truth. (2020) U sferi turyzmu bilshe polovyny robochykh mists mozhut znyknuty [In the field of tourism, more than half of jobs may disappear]. Ekonomichna pravda [Economic truth] (electronic journal). Available at: https://www.epravda.com.ua/ news/2020/10/31/666801 (accessed 01 November 2020).

4. Interfax Ukraine (2020) Chyslo turystiv na khutorakh Odeskoi, Mykolaivskoi ta Lhersonskoi oblastei zroslo na 30\% - "Vodafone Ukraina" [The number of tourists in the resorts of Odessa, Mykolaiv and Kherson regions has increased by 30\% - "Vodafone Ukraine"]. Interfaks Ukraina [Interfax Ukraine] (electronic journal). Available at: https://interfax.com.ua/news/telecom/673327. html (accessed 26 October 2020).

5. World Travel \& Tourism Council (2020) To Recovery \& Beyond: The Future of Travel \& Tourism in the Wake of COVID-19. Analysys. World Travel \& Tourism Council (WTTC). Available at: https://wttc.org/Research/To-Recovery-Beyond (accessed 01 November 2020).

6. Daily electronic newspaper of the Russian Union of Travel Industry (2020) UNWTO prizyvaet k podderzhke ekonomiki cherez sektor puteshestvii i turizma [The UNWTO calls for economic support through the travel and tourism sector]. Ezhednevnaia elektronnaia gazeta Rossiiskogo soiuza turindustrii [Daily electronic newspaper of the Russian Union of Travel Industry] (electronic journal). Available at: https://ratanews.ru/news/news_6042020_6.stm (accessed 21 April 2020).

\section{ПУТИ УМЕНЬШЕНИЯ НЕГАТИВНОГО ВЛИЯНИЯ ПАНДЕМИИ КОВИД-19 НА РАЗВИТИЕ ТУРИЗМА В МИРЕ И В УКРАИНЕ}

Аннотация. В статье рассматривается влияние пандемии COVID-19 на туристический рынок мира и Украины. Отмечено, что любой кризис неизменно ведет к появлению новых возможностей. Проанализированы основные тенденции влияния пандемии на различные сектора сферы гостеприимства, которые свидетельствуют, что больше всего кризис затронул международный туризм, а меньше всего - внутренние путешествия. Рассмотрены возможные направления по которым будет развиваться туристическая сфера в будущем. А именно: повышение требований к безопасности путешествий, индивидуализация туризма, широкое использование новейших информационных технологий в туризме, использование идей экономики впечатлений, расширения географии туристических маршрутов. Предложены пути смягчения негативного влияния данного кризиса на отечественные туристические предприятия на основе использования зарубежного опыта. Украинским туристическим предприятиям рекомендовано сосредоточиться на восстановлении прежде всего внутреннего туризма, туристические компании при содействии правительства могут подготовить несколько длинных рекреационных туристических маршрутов (с запада на восток, с севера на юг), разместив вдоль них торговые точки, гостиницы,, организовав развлечения на свежем воздухе, рестораны со скидками и т. п.

Ключевые слова: туризм, туристический рынок, пандемия COVID-19, кризис, внутренний туризм, перспективы восстановления, пути преодоления кризиса, инновации в туризме.

\section{ШЛЯХИ ЗМЕНШЕННЯ НЕГАТИВНОГО ВПЛИВУ ПАНДЕМЇ̈ КОВІД-19 НА РОЗВИТОК ТУРИЗМУ В СВІТІ ТА В УКРАЇНI}

Анотація. У статті розглядається вплив пандемії COVID-19 на туристичний ринок світу та України. Зазначається, що будь-яка криза призводить до нових можливостей. Проаналізовано основні тенденції впливу пандемії на різні сектори гостинності, які показують, що криза найбільше вразила міжнародний туризм, а найменше внутрішні подорожі. Розглядаються можливі напрямки, в яких туристична сфера буде розвиватися в майбутньому. А саме: підвищення вимог до безпеки подорожей, індивідуалізація туризму, широке використання новітніх інформаційних технологій у туризмі, використання ідей економії вражень, розширення географії туристичних маршрутів. Запропоновано способи пом'якшення негативного впливу цієї кризи на вітчизняні туристичні підприємства на основі використання іноземного досвіду. Перш за все, туристичним компаніям у світі та в Україні слід ретельно відстежувати зміни попиту на туристичні послуги та намагатись максимально швидко та повно їх задовольнити, що дозволить зменшити негативний вплив 
на цей сектор. Також вітчизняні туристичні компанії можуть реалізувати такий вид туризму в умовах пандемії, як створення віртуальних турів. Прогнози свідчать про те, що через пандемію ринок ділового туризму переживає глибокий і незворотний спад. Тому ті вітчизняні та іноземні туристичні підприємства, які в основному займаються організацією ділового туризму, повинні негайно переорієнтуватись на інші сфери. Для готелів, які, як і решта підприємств індустрії гостинності, переживають глибоку кризу, рішенням може бути переорієнтація на надання тимчасового житла людям, які перебувають у ізоляції або орендують кімнату для віддаленої роботи, не маючи можливості працювати вдома. Готелі також можуть продати ваучери на майбутнє проживання за зниженою ціною сьогодні, але з перспективою зростання цін у майбутньому. Українським туристичним компаніям рекомендується зосередитись насамперед на відновленні внутрішнього туризму, туристичні компанії за сприяння уряду можуть підготувати кілька довгих рекреаційних туристичних маршрутів (із заходу на схід, з півночі на південь), розмістивши вздовж них торгові центри, житло, розваги на свіжому повітрі, ресторани зі знижками тощо.

Ключові слова: туризм, туристичний ринок, пандемія COVID-19, криза, внутрішній туризм, шляхи подолання кризи, інновації в туризмі. 